\title{
Anti-diabetic Uses of Some Common Herbs in Tribal Belts of Midnapur (West) District of Bengal
}

\author{
Analava Mitra \\ B.C. Roy Tech Hospital \& Adjunct Faculty, School of Medical Science and Technology, \\ Indian Institute of Technology, Kharagpur 721 302, West Bengal, India \\ Telephone: 03222-282657; Fax: 03222-282631; E-mail: amitra@adm.iitkgp.ernet.in
}

KEYWORDS Type 2 diabetes; tribes; herbal principles; life style; diet

\begin{abstract}
India is facing diabetic explosion. The cause may be both nature and nurture. Life style and diet, the factors primarily responsible, can be altered and modified to reduce the incidence. India has a rich heritage of different cultures and religions including that of tribes. Tribal influence pervades the religions, languages, medical and agricultural practices of India. Being a part and parcel of India, tribals are susceptible to diabetes also, though the incidence is less in them. They developed indigenous patterns of health care suiting their economy, culture and socio-religious perceptions. This article deals with the plant products commonly used by them as anti-diabetic measures.
\end{abstract}

\section{INTRODUCTION}

\section{Diabetic Explosion in India}

As per King et al. (1998) incidence of diabetes in India will increase by $195 \%$ in 2025 and the sufferers will be young age individuals. Type 2 diabetes along with its fore-runner Impaired Glucose Tolerance (IGT) is a result of Insulin Resistance (IR) and is commonly associated with Obesity, hypertension, Coronary Artery Disease (CAD) and Dyslipidaemia. The disease is affecting at an alarming rate to both rural and urban populations in India (Mohan et al., 2001, 2006; Ramachandran et al., 1990, 2001; http:// news.hitavadaonline.com/news/index.php? mode $=$ single $\&$ page $=11 \& n=6546)$.

Table 1 (Prevalence of diabetes and impaired glucose tolerance (IGT) in different cities in India) shows the prevalence of Diabetes and impaired glucose tolerance (IGT) in different cities in India (Ramachandran et al., 2003).

\section{Incidence in Different Cities of India}

Researchers found that incidence of diabetes are more on the Southern parts of the country and least in the Eastern parts. Nearly 12 per cent of the adult population in Delhi and Kolkata, nearly 10 per cent in Mumbai, 12.5 per cent in Bangalore, 13.5 per cent in Chennai and nearly 16 per cent in Hyderabad are patients of diabetes. The incidence of diabetes had increased in Hyderabad with an average of 16 per cent above the age of 25 suffering from the disease as compared to five per cent in other cities and world average of three percent. However, in rural areas the incidence was five per cent less. The Diabetes Awareness Survey in Hyderabad (DASH) study conducted in the twin cities has recently pointed out that the diabetes prevalence levels have grown significantly from 16.6 per cent as per the National Urban Diabetes Survey (NUDS) of 2001. Stating that the exact reasons for the growing prevalence rate of diabetes in Hyderabad were not yet ascertained, The DASH study has revealed that nearly 43 per cent of the Hyderabad population was unaware of a condition called diabetes and 65 per cent did not know that diabetes could affect the eyes, which could lead to decreased sight. The increased prevalence of diabetes in India has a lot to do with a switch from a traditional to a Western diet though the traditional Indian diet is good for diabetes (http:/ /news.webindia123.com/news/showdetails. asp?id=231251\&cat=Health)

\section{Possible Causative Factors}

Diet: Diet has a profound role in the control of such diseases as observed by several observers (Raheja et al., 1970; Sanders et al., 1985; Ghafoarunissa, 1996; Ornish, 1996; Luscombe et al., 2002; Mitra and Bhattacharya, 2005, 2006). Mitra and Bhattacharya $(2005,2006)$ found while rural diet is diabetogenic in nature, increase in protein content in the diet was easier to comply and more satiating. It caused reduction 
Table 1: Prevalence of diabetes and impaired glucose tolerance (IGT) in different cities in India

\begin{tabular}{lcccc}
\hline City & $n$ & Males:Females & Diabetes\% $(95 \%$ CI $)$ & IGT\% $(95 \%$ CI $)$ \\
\hline Chenni & 1668 & $708: 960$ & $13.5(11.8-15.2)$ & $16.8^{\mathrm{b}, \mathrm{f}}(14.6-19.0)$ \\
Bangalore & 1359 & $638: 721$ & $12.4^{\mathrm{b}}(10.5-14.3)$ & $14.9^{\mathrm{b}, \mathrm{f}}(12.8-16.9)$ \\
Hyderabad & 1427 & $685: 742$ & $16.6(14.6-18.6)$ & $29.8^{\mathrm{f}}(26.9-32.8)$ \\
Calcutta & 2378 & $1163: 1215$ & $11.7^{\mathrm{a}, \mathrm{b}}(10.4-13.0)$ & $10.0^{\mathrm{a}, \mathrm{b}, \mathrm{d}}(8.7-11.4)$ \\
Mumbai & 2084 & $987: 1097$ & $9.3^{\mathrm{a}, \mathrm{b}, \mathrm{c}}(7.7-10.1)$ & $10.8^{\mathrm{a}, \mathrm{b}, \mathrm{d}}(9.3-12.2)$ \\
New Delhi & 2300 & $1107: 1193$ & $11.6^{\mathrm{a}, \mathrm{b}}(10.3-12.9)$ & $8.6^{\mathrm{a}, \mathrm{b}, \mathrm{d}, \mathrm{e}, \mathrm{f}}(7.4-9.7)$ \\
\hline
\end{tabular}

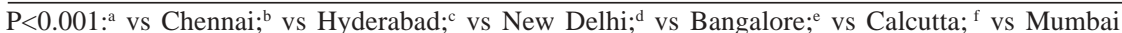

of abdominal fat in males. This corroborates with the observations of Luscombe et al. (2002). Ghafoarunissa (1996) observed that in Indian rural diet fat intake, particularly intake of omega-3 fatty acid, is low and intake of fat is directly proportional to income. Sanders et al. (1985) showed that with a low fat intake the difference in effects of w-3 and w- 6 fatty acids are marginal. Hence, the view expressed by Sanders et al. was contrary to the view expressed by Raheja (1999) who links the diabetic explosion in India, to increase in consumption of omega -6 fatty acids which started from mid 70s in order to reduce blood cholesterol levels and subsequent coronary artery diseases therein. Ornish (1996) had advocated a low fat diet is beneficial for health but it has the disadvantage of low HDL level in blood. Hence, a diet with adequate fat and with w-3 and w- 6 fatty acids is good for health. It was observed that vegetarian diet has a role in reducing the incidence of Insulin Resistance (IR) (Burslem et al., 1978; Burr and Sweetman, 1982; Ernst et al., 1986; Fisher et al., 1986).

Body-mass Index: While most people get diabetes if their body-mass index is 30-31, in the case of Indians, a body-mass index of above 25 is enough for them to get diabetes. The ideal body mass index by international standards is 25 and below, but the ideal body mass index for an Indian should be 23 and below. Only five per cent of the surveyed individuals knew that sedentary lifestyle was a risk factor for diabetes.

Other Factors: Sedentary lifestyle, genetic susceptibility, environmental and lifestyle changes resulting from industrialization and migration to urban environment from rural settings could be responsible for high incidence of the disease. Compared to the Chinese, the Europeans, or the Koreans, urban Indians do not have the habit of exercising. Sporting activities are not part of the Indians' lifestyle, which prefer a sedentary life to an active life. Indians, frankly, prefer sitting in front of the television to taking a walk (http:// news.hitavadaonline.com/news/index.php? mode $=$ single $\&$ page $=11 \& n=6546$ ) .

Interpopulation Differences: Interpopulation differences exist in both diet and the socio-cultural factors both within and outside the subcontinent. Available data suggest that diet is the main culprit. NIDDM prevalence rates are higher on the east coast of Andhra Pradesh, particularly Eluru and Tenali, where rice is traditionally consumed as only cereal were higher compared with urban and rural Hyderabad, mainly wheat eating community. The dietary pattern, eating and methods of cooking vary in different parts of India (Ramaiya et al., 1990). Mitra and Bhattacharya (2005, 2006) found diet in the rural Bengalee communities has a role to play in the incidence of Type 2 Diabetes and the condition improves with diet prescribed as per ADA guidelines (1987). Since then attempts have been made to assess the role of diet to diabetes in population surveys. Diet may contribute to the development of diabetes in two ways: quantitatively, by supplying calories and if activity is low by resultant obesity and qualitatively by the effects of specific foods. The long term effects of intermittent starvation and the pathological metabolic stress consequent to it on the course of glucose tolerance are not known still yet though some populations in India, where incidence of diabetes is on higher side (tribal belts of Rajasthan and Gujrat) consume very little protein on some days and an alternate starvation-excess cycle exists (Ramachandran et al., 1990).

Effects on Migration: However, with migration, the traditional dietary pattern changes rapidly with an increase in the consumption of "modern" foods coping with the west where changes in dietary adjustments has extended over many generations leading to genetic adjustments. Traditionally, Hindu Indians are pure vegetarians, but with modernization the diet has become more lactovovegetarian. In addition to the use of meat, fish, and poultry with moderate use of eggs, dairy products, and a relatively high intake of vege- 
tables oils. Hence the intake is of less saturated fat and cholesterol, and more poly-unasaturated fat and vegetable fibre (Mitra and Bhattacharya, 2006). Some workers believe that a vegetarian diet reduces the risk of developing diabetes but in a multicentre Indian study diabetes was more prevalent in vegetarians $(2.1-2.8 \%)$ than in nonvegetarians $(<2 \%)$. In Tanzania, Hindu Indians, majority of whom are vegetarians also had a higher prevalence of diabetes than Muslim Indians who are non-vegetarians. Asian Indians living in America maintaining Indian dietary habits have higher insulin levels, higher plasma glucose levels and lower insulin binding to erythrocytes after a glucose load than Caucasoid Americans, suggesting an increased risk of developing NIDDM, though the risk reduces in $2^{\text {nd }}$ generation of American Indians (Ramaiya et al., 1990). The contribution of diet, therefore, to the increased prevalence of diabetes in Asian Indians is still hazy and more nutritional studies are required to know the specific contribution of diet, independent of obesity to the pathogenesis of type 2 diabetes. WHO Expert Committee opined that the undernutrition protects populations against diabetes and as undernutrition is common in India, incidence of diabetes should be less in Indians, but on the contrary, it is more. Indian lifestyle habits, especially diet, might be invoked to explain the increased susceptibility to glucose intolerance based on Neel's thrifty genotype hypothesis and Dilman's theory of failure in adaptosis mechanism (Dilman, 1989). While it is possible that some of these factors are either racially or genetically predetermined (Mohan et al., 1996; Misra et al., 2001; Harris et al., 2002) prime factor for the increase could be the adverse life style patterns (Ramachandran et al., 2003).

Birth Weight and Childhood Developments: The results of a long follow-up of children from birth to 30-35 years have brought out certain factors during early childhood that lead to diabetes in later life. In a meticulous analysis of the children whom they followed from birth through their early adulthood, the researchers found that heavy mothers give birth to bigger babies who later on become obese adults. They also found that, paradoxically, the babies who have a low birth weight tend to grow rapidly in childhood and become obese adults. This phenomenon is already noticeable in the developing countries where with availability of better nutrition, particularly for boys, there are sudden spurts of growth leading to obesity, which in turn is an important factor in the development of diabetes. The critical period of growth for the children is early childhood and indeed even earlier than that, the intrauterine life. These observations point towards the possibility of intervention during these phases of life, which makes more economic and medical sense than developing drugs for diabetes. The fasting glucose level in the children was not high to begin with but stressing the system by giving higher dose of glucose brings out the presence of diabetes. The efforts need to start during the intrauterine life, early childhood and adolescent life. An enormous effort to educate the community is needed. Infants who are at the highest end of the distribution for weight or body mass index or who grow rapidly during infancy is at increased risk of subsequent obesity (Baird et al., 2005).

Effects of Life Style: No wonder the WHO has declared this year as the year of Lifestyle Changes (The Tribune, 21.4. 2002). Stress as a result of faulty life-style may lead to more of visceral obesity (Drapeau et al., 2003) and increase in waist circumference leading to increase in insulin resistance (Wahrenberg et al., 2005).

This rising trend predicts a significant health burden due to diabetes in India. This problem started developing in the childhood more in the urban areas where children do not have any kind of physical exercise and consequently the lifestyle pattern is altered. The only thing one does is to spend long hours on the computer or the cell phone or watch television (http://www. chennaionline.com/health/News/2005/09 diabetes.asp). As per data provided by US Census Bureau, Population Estimates, 2004 and US Census Bureau, International Data Base, 2004 further study is needed regarding role of geographical variables, particularly longitude and latitude.

Western lifestyle is the fast emerging as the biggest threat contributing to the sharp rise in the incidents of diabetes in India. This is the result of coca-colanisation or mcdonaldisation of life styles. Much has been said about the socioeconomic changes sweeping across India and the effect it is having on the population. Prevalence of diseases hitherto considered "rich man's disease", are disturbingly on the rise across all categories of society. One of the most morbid among these is Diabetes Mellitus.

Economic Impact of the Disease: The cost 
of treatment of this disease per se and its accompanying complications can ruin families. The median annual direct medical cost for patient with Type-II DM without complications was Rs. 14,507/- (Bhaskaran et al., 2003).

\section{Alternative Therapies}

The involved cost and lack of infrastructure, prevailing in rural India gives a scope to incline to its traditional source of healthcare through Ayurved, particularly in the use of medicinal herbs and plants. Mankind has a long history in the use of herbal medicines. Rigveda and Ayurveda (4500-1600 BC) reveal that ancient Indians had a rich knowledge of the use of medicinal plants. India unquestionably occupies the topmost position in the use of herbal drugs since ancient times utilizing nearly 600 plant species in different formulations. Great majorities of people in India have been depending on crude drugs for the treatment of various diseases as evidenced from well-documented indigenous system of medicines, Ayurveda and Unani. The Materia Medica of these systems contains a rich heritage of indigenous herbal drugs (Nadkarni, 1954). The role of traditional medicines in the solution of health problems is invaluable on a global level. This is more striking when we consider the fact that approximately $80 \%$ of the people living in less developed countries rely exclusively on traditional medicine for their health care needs. Traditional Indian and Ayurvedic medical system for example, have been evolved during thousands of years and have left for posterity a well documented literary legacy which permits us to recognize immediately a theoretical base whose conceptual framework even if were more or less archaic is found to be logical. In other countries the ethnomedical heritage has not reached a high status. However, many useful points can still be found in them. The sources, which support the popular harmacopoeia, are raw materials of vegetable, animal and mineral origin. However, the most important therapeutic resource is that of vegetable origin. They are qualitatively and quantitatively superior to the other two. Often impregnated with contradictory religious creeds we find plants used as proper medicines, food and no less importantly plants used in religious rituals acknowledged as 'placebo' or those used in 'baths'. The last two specifically plants as scholars do not consider 'foods' in their truthful magnitude and they are relegated to the background unfortunately. Well documented is the hot-cold dichotomy at least in relation to plants considered in such manner. There are abundant data on the role of wind, hot, humidity and cold in the genesis of many afflictions. In general, the plants are used fresh, mainly as decoction, even though the plant has therapeutically active volatile components (Santana, 1996). Over the years, the tribal community developed an intimate knowledge of various plants and their medicinal uses played an invaluable role in the development of Ayurvedic medicines. According to the studies on ethnomedicine and folk medicine about 2000 species are newly identified as drug yielding plants and are well known for their use in about 4000 drug industries of various Indian system of medicine.

\section{Role of Culture}

The rich cultural reservoir of traditional Indian medicine is supported by diverse cultural sources, which have to be evaluated fully. It represents the people. The popular therapeutic habits and successes have to be retrieved and validated in order to use this information to develop new costeffective, safe and efficacious system of medicines. A national congress on traditional sciences and technologies of India during 1993 was organized specifically to comprehend and evaluate our traditions in diverse domains of knowledge and practice. This was considered an important issue in our developmental efforts at the grass-root levels, as many of these living traditions still have the potential to contribute to the physical well being of our people (Seshadri, 1993). India's customs and social patterns are at their present levels mainly because of tribal people. As an example, the earliest tribes heavily stressed gender equality and respect for all members. With their influence, deities, customs, myths and other, religious rites were absorbed into broad stream Indian society. Such a valuesystem was sustainable as long as the tribal community shared the fruits of their labor. Nevertheless, tribal societies were under constant pressure as the money economy grew and made traditional forms of barter difficult to sustain. Tribal influence also pervades the religions, languages, medical and agricultural practices of India. The Gods Shiva, Kali, Krishna, and Ganesh 
all have tribal backgrounds. In the eighth century, the tribal forest goddess, Parvati, became Shiva's wife. Ganesh origins come from a tribe of elephant trainers. The languages of Oriya, Marati and Bengali developed by integration of tribal and local languages. Tribals also played an important role in the development of agricultural practices like rotational cropping and fertility maintenance (Sarkar and Dasgupta, 2000; Saraswati, 2004).

\section{TRIBAL POPULATION IN INDIA PARTICULARLY BENGAL}

The tribal population of India appears to be an insignificant $8.08 \%$ on first glance. However, when translated into figures, it amounts to more than 80 million people, which is more than the population of many developed countries of the world. A major part of this population resides in the belt that constitutes Jharkhand (7.7\%), Chattishgarh, Orissa $(22.2 \%)$ and West Bengal (5.6\%) (http://tribal.nic.in/tribes.html). Although the states of the north-eastern region constitute chiefly of tribal population, since they are small states, in terms of real number of tribals, states like Jharkhand (Chattishgarh, Orissa and West Bengal, far exceed that number. In Orissa the major tribes are the Birhor, Gond, Juang, Khond, Korua, Mundari, Oraon, Santhal, Tharua, etc. In Bihar and Jharkhand, are the Asur, Banjara, Birhor, Korwa, Munda, Oraon, Santhal and in West Bengal are the Asur, Birhor, Korwa, Lepcha, Munda, Santhal and other tribes (http:// tribal.nic.in/theconstitutionbystate.html ). The condition of the tribal populace is so bad that almost half the population lives below the poverty line and suffers from serious malnutrition (Singh, 1993). Poverty is not the only cause for this malnutrition. To a very great extent, their food habits and lack of awareness of nutritional facts, socio-cultural factors like the taboos and beliefs within which they live are responsible for this state of affairs. In fact, the majority of pre-school tribal children suffer from malnutrition for these reasons (Rao et al., 2005).

\section{Health Problems of Tribes}

The inadequate health infrastructure for these peculiar health needs of the tribal is also a major factor. The problem of tribal health and nutrition is linked with social, economic and educational status of the tribal. The tribal demographic scenario is one of high fertility, high maternal and infant mortality rates. Poverty, illiteracy, malnutrition, lack of personal hygiene, unsanitary conditions and absence of health education, poor mother and child health services and poor coverage of the national preventive programmes have been found responsible for the poor health of the tribal communities. Besides poor coverage, the tribal communities have their own systems of medicines, dispensed through the medium of shamans, herbalists and witchdoctors, which also act as a barrier to healthcare programmes. The government of India has implemented specific programmes for the healthcare development of the tribal communities and there have been encouraging results. Both at Central and State Government level various welfare measures have been adopted to promote the quality of life during the five decades of our independence. But no significant change seems to have taken place in their life-style. It is observed that the privileged section of the society shares the fruits of any sort of development. These people live in remote and hilly regions with a little contact with people from plains. They venerate every aspect of life. Shifting Agriculture is the main stay of the population. They depend on minor millets as staple food. They are very hardworking people, sincere, and trust worthy. Due to small amount produce from agriculture they have remained poor. Consequently they are anaemic, and suffer from diseases such as malaria, tuberculosis, and infertility. Personal and menstrual hygiene of women is in a bad state and suffer from white discharge and several menstrual problems. Many women and men have been widowed due to deaths resulting out of malaria. The tribal communities suffer two groups of diseases. The first group includes those diseases, which have their origin in poverty and backwardness; the other group of diseases includes those diseases, which they have contracted from modern civilization. Often some dreaded diseases are now endemic to the tribal areas (Robin and Sherry, 2004). Many of the tribal began to succumb to diarrhea, malaria, and snakebites.

Primitive tribes are highly receptive and amenable for discussions on several of their problems. Usual surveys may not help in identifying their problems. Informal discussions and interviews will reveal their cultural life. They need continuous interaction with people from plains to develop their life. Many of the illnesses ravaging this 
community can be prevented by basic health education, first aid, and proper hygiene, and better care of the natural resources (Robin, 2004).

\section{Anti-diabetic Use of Some Common Plants by Tribes}

Ayurveda and other traditional approaches had described anti-diabetic potentials in more than 800 plants in the Indian sub-continent (Rahman and Zaman, 1989; http://tribal.nic.in/ theconstitutionbystate.html). Tribes usually go for those plants, which are easily available, and involve no cost or very less costs. Due to its wide spread availability they are used as a medicinal plant by a section of Munda and Santhal tribes of Midnapur district. The plants commonly used by them are Banyan tree, Currey leaves, Jamun seeds and leaves, Bitter gourd and gurmur.

Banyan Tree: Its active anti-diabetic compounds rests in its bark and leaves (Sushrut Samhita Nidan 6.6; http://www.ayurvedinstitute .com/diseases_diabetes2.htm; Chopra and Chopra, 1955; http://www.plantcultures.org.uk/ plants/banyan_traditional_medicine.html; Bhattacharya, 1977; http://www.herbalgram. org/ herbclip/review.asp?i=43536; Rahman and Zaman, 1989 and http://www.wisegeek.com/whatis-a-banyan-tree.htm). A decoction of bark is to be prepared and consumed twice daily in a dose of 40 to $80 \mathrm{ml}$. The decoction is prepared by taking around 25-50gms of bark to which 4 cups of water are to be added $(100 \mathrm{ml}$ of $10 \%$ solution). It is heated to make one cup, which has to be consumed (Chopra and Chopra, 1955). So far, some compounds called leucocyanids have been isolated from the tree and these compounds could be associated with the anti-diabetic activity of the plant. However, more research needs to be completed to understand the medicinal properties of this symbolic tree. The plant is not reported as being used medicinally in Europe and there are no documented cases in the literature of toxicity from its use in Britain (Deshmukh, 1960; Shrotri and Aiman, 1960; Vohra and Parasar, 1969; Vohra and Parasar 1970; Singh et al., 1992).

The latex obtained from the aerial parts of the plant (leaves and young branches) and mixed with honey and use orally to control high blood glucose level (http://www.ayurvedinstitute.com/ diseases_diabetes 2.htm). It is less effective in patients with normal sugar and the effect is due to glycosides (Bengalenoside) (Satyavati et al., 1989).

Fiscus contains albuminoids (fruits), caoutchouc, carbohydrates, fibers, flavonols, friedelin (leaves), glycemic principles and glycoside (bark), oil (fruit), quercitin-3-galactoside (leaves), rutin and sitosterol (leaves), subramanian (heartwood), tannins 10\% (bark and buds), taraxosterol acid ester, tigilic acid ester, triterpene (leaves), wax (Blake, www.naturalhealthwizards. com).

Two anti-diabetic glycosides (still in experimental process) were isolated from banyan tree (Ficus bengalensis) bark. They are active at a much smaller dose of $10-25 \mathrm{mg} / \mathrm{kg}$ body weight in contrast to $100 \mathrm{mg} / \mathrm{kg}$ of body weight required for other glycosides of banyan bark isolated earlier by others. They were tested in diabetic rabbits. They are useful not only in mild diabetes but also severe diabetes in which pancreas is almost completely destroyed. Other glycosides and flavonoids isolated from banyan bark are not useful in severe diabetes. These two drugs have the advantage that they need not be taken every day. They are effective even when given intermittently. The beneficial effects continue for 10 days after stopping effective treatment. They are different from the glycosides and flavonoids isolated by others earlier. They did not produce any toxic effects during the period of treatment in the rabbits. Histopathological studies revealed that some of the abnormalities seen in the pancreas of untreated rabbits are corrected. Further the mechanism of action seems to be both by increasing serum insulin levels as well as by directly acting on liver and muscle enzymes involved in glucose metabolism i.e. pancreatic and extra pancreatic. There were no toxic effects during the period of treatment (http://www.nrdcindia.com/ pages/bioactivecompounds.htm; Achrekar et al., 1991).

Curry Leaves: Curry leaf (Murraya koenigii Spreng) contains special compounds that inhibit alpha amylase. This means that the rate at which starch is broken to glucose can be slowed by inhibiting the metabolic reaction of the enzyme. This is potentially a breakthrough for diabetes sufferers. Slowing the rate of starch breakdown, by blocking the alpha-amylase enzyme, can lower the rate at which glucose enters the bloodstream from the intestine. This breakthrough could lead to the development of a new drug for diabetes. This is important because more and more people, 
especially young people, are developing diabetes because they are eating food that contains too much sugar. New drugs which have few sideeffects are constantly being sought. It may not be too long before the curry leaf emerges as a new innovative medicine (http://www.plant cultures.org.uk/plants/curry_leaf_western medicine.html). Tribals use green leaves as such and usually takes 15 leaves per day.

Jamun: When alloxan induced diabetic rats were fed with Jamun seed extract, the blood glucose, blood urea, serum cholesterol and serum triglyceride levels were found to decrease significantly (Giri et al., 1985). Jamun fruit reduces the sugar in the blood and is very good in the control of diabetes. Its seeds contain Glucoside, Jamboline and Ellagic acid, which are reputed to have the ability to check the conversion of starch into sugar in case of excess production of glucose. Therefore, Jamun seeds are also used as a remedy for Diabetes. "Shaligram Nighantu Pharmacopia" in ancient India also confirmed use of Jamun seeds for Diabetes. Jamun seeds reduce urine sugar quickly. Other constituents of the fruit include Resin, albumen, gallic acid, essential oil and tannic acids (http://www.healthandyoga.com/html/ product/diabetic.html). Tribals use Jamun leaves as such in diabetes needing further studies to show the efficacy of the leaves. 5-6 leaves per day are commonly chewed in morning before the breakfast.

Bitter Gourd: Number of studies depicts the effects of bitter gourd in diabetes. Tribals usually use the bitter gourd plants and leaves for anti diabetic effects. The tip of the plant is usually consumed along with leaves about 15 grams twice or thrice weekly. Results from a recent study of bitter gourd in diabetic mice have suggested that this vegetable, which features in many local dishes, has a favorable effect on blood glucose levels. Although the mice were only studied for a month, the researchers are confident that this is a significant breakthrough in scientifically validating the traditional use of the plant. The other purported benefits of bitter gourd lay in its antibacterial, antibiotic, anti-inflammatory, antioxidant and antiviral properties. Feeding bitter gourd for two weeks may have stimulated the body to help in some way, either to directly produce more insulin or activate the pancreatic beta cells to produce more insulin. Another possible, although less likely, mechanism of action is that bitter gourd makes the receptors of target cells (like muscles and fat tissues) more sensitive to insulin, and therefore, the cells increase their absorption of glucose. At least three different groups of constituents in the bitter gourd appeared to have hypoglycemic, blood sugar lowering, actions of potential benefit in diabetes mellitus. It is believed that these include a mixture of steroidal saponins known as charantin, insulin-like peptides, and alkaloids. The bitter melon is believed to improve glucose tolerance in Type II diabetes. Active constituents are believed to be oleanolic acid glycosides and Momordins which prevent absorption of sugar (Mitra and Bhattacharya, 2006).

Gurmur: Mitra and Bhattacharya (2006) used a composite with Gurmur and tested it in newly diagnosed type 2 diabetes patients between 45 and 60 years of age for 4 weeks. The parameters used for evaluation were blood glucose levels and glycosylated hemoglobin $\left(\mathrm{HbA}_{1} \mathrm{c}\right)$. Of the three cardinal symptoms for diabetes, a marked reduction was observed for polyuria (the production of large volumes of urine). The other two symptoms, symptoms polyphagia (gluttonous excessive eating) and polydipsia (abnormally intense thirst), initially observed were disappeared by 12 weeks. Control of both fasting and postprandial blood glucose was achieved in about $55 \%$ of patients. Only $7 \%$ of the patients attained control of $\mathrm{HbA}_{1} \mathrm{c}$ by 4 weeks. None of the patients reported any side effects.

The Indian Council of Medical Research concluded that Gurmur be used in the treatment of newly diagnosed or untreated Type 2 diabetes patients. In addition they suggested that the treatment be restricted to mild diabetics preferably in combination with other herbal remedies like Vijayasar (http://www.webindia123.com/health/ disease/diab/care.htm).

\section{CONCLUSION}

Tribals in India have a rich heritage. Modern traditional medicine owe a large to tribal medicines and many resarches are being conducted for scientific explanations. Tribal populace being poor and weak economically, their medicines suit to majority of Indians as it is affordable. Cultural variations act as a hindrance to universal acceptability. However, herbal principles can be safely analysed for future acceptability in majority of Indians as alternative medicines of choice. This paper provides research directives to leaves of 
banyan, leaves of Jamun, tip of the stem and leaves of bitter gourd, leaves of curry and gurmur as anti-diabetic principles.

\section{REFERENCES}

Achrekar, S., G.S. Kaklij, M. S. Pote, and S. M. Kelkar. 1991. "Hypoglycemic activity of Eugenia jambolana and Ficus bengalensis: mechanism of action". In Vivo, 5(2): $143-147$

ADA. 1987. "Nutritional Recommendations and Principles for People with Diabetes Mellitus." Diabetes Care, 23(1): 1-9.

Anonymous. 2002. Obesity in childhood can lead to diabetes. Fitness Spectrum, The Tribune, Daily April 21, 2002 page 7

Baird, J., D. Fisher, P. Lucas, J. Kleijnen, H. Roberts, and C. Law. 2005. "Being big or growing fast: systematic review of size and growth in infancy and later obesity." BMJ, 331(7522): 929.

Bhaskaran, V.P., N.R. Rau, Satyashankar Acharya, Ravi Raj, S. Chinnappa, Metgud Koshy and A. Tarun. 2003. "Study of the Direct Costs Incurred by Type2 Diabetes Mellitus Patients for their Treatment at a Large Tertiary-Care Hospital in Karnataka." India Journal of the Academy of Hospital Administration, 15(2): $7-12$.

Bhattacharya S. 1977. Chirangeebee Banoushadhi. Calcutta: Ananda Publishers Private Limited.

Blake, Steve. 2006. Herbal Reference E-Books, Medicinal plant constituents. Retrieved July 4, 2006 from http:/ /www.naturalhealthwizards.com/.

Burr, M.L. and P.M. Sweetman. 1982."Vegetarianism, dietary fibre and mortality." Am. J. Clin. Nutr., 36: 873-877.

Burslem, J., G. Schonfeld, M.A. Howald, S.W. Weidman and J.P. Miller. 1978. "Plasma apoprotein and lipoprotein lipid levels in vegetarians." Metabolism, 27: 711-719.

Chopra, R.N and I.C. Chopra. 1955. A Review of Work on Indian Medical Plants. New Delhi: ICMR.

Deshmukh, V.K. 1960. "Isolation of a hypoglycemic principle from the bark of Ficus bengalensis." Ind. J. Physio. and Pharmacol., 4: 182.

Dilman, V.M. 1989. The Grand Biological Clock. Moscow: Mir Publishers.

Drapeau, V., F. Therrien, D. Richard and A. Tremblay. 2003. "Is visceral obesity a physiological adaptation to stress?" Panminerva Medicine, 45(3): 189-195.

Ernst, E., L. Pietsch, A. Matrai and J. Eisenberg. 1986. "Blood rheology in vegetarians." Brit. J. Nutr., 56(3): 555-560.

Fisher, M., P. H. Levine and B. Weiner. 1986. "The effect of vegetarian diets on plasma lipid and platelet levels." Arch. Intern. Med., 146: 1193-1197.

Ghafoarunissa. 1996. "Fats in Indian diets and their Nutritional and health Implications." Lipids, 31: 287291.

Giri, J., T. K. Sathidevi, and N. Dushyanth. 1985. "Effect of Jamun seed extract on alloxan induced diabetes in rats." Journal of the Diabetic Association of India, 25(4): 115-119.

Harris, S.B., B. Zinman, A. Hanley, J. Gittelsohn, R. Hegele, P. W. Connelly, B. Shah, J. E. Hux. 2002.
"The impact of diabetes on cardiovascular risk factors and outcomes in a native Canadian population." Diabetes Res. Clin. Pract., 55: 165-73.

Joglekar, G.V. 1962. "Further studies on ficus bengalensis Linn. I toxicity tests." Ind. J. Med. Res., 50: 747.

King, H., R.E. Aubert and W.H. Herman. 1998. "Global burden of diabetes, 1995-2025: prevalence, numerical estimates, and projections." Diabetes Care, 21: 1414-31.

Kohli, K.R. 2006. Diseases and cures, Managing diabetes through Ayurveda. Retrieved July 8, 2006 from http:/ /www.ayurvedinstitute.com/diseases diabetes2.htm.

Luscombe, N.D., P.M. Clifton, M. Noakes, B. Parker and G. Wittert. 2002. "Effects of energy-restricted diets containing increased protein on weight loss, resting energy expenditure, and the thermic effect of feeding in type 2 diabetes." Diabetes Care, 25: 652-657.

Mitra, A and D. Bhattacharya. 2005. "Effects of overall consumption, dietary patterns, cooking, on patients suffering from Non insulin dependent diabetes mellitus." J. Interacademicia, 9(4): 635-642

Mitra, A and D. Bhattacharya. 2006. "Effect of Fatty Substances on Health particularly to Patients Suffering from NIDDM and Dyslipidaemia." $J$. Interacademicia, 10(1): 74-85.

Mitra, Analava and D. Bhattacharya 2006 Effects of a Composite of Tulsi leaves, Amla, Bitter Gourd, Gurmur leaves, Jamun fruit and seed in Type 2 diabetic patients with Dyslipidaemia. African Journal of Health Sciences, (in press).

Mohan, V., R. Vijayaprabha and M. Rema. 1996. "Vascular complications in long-term south Indian NIDDM of over 25 years' duration." Diabetes Res. Clin. Res. Pract., 31: 133-140.

Mohan, V., C. S. Shanthirani, Deepa Raj, G. Premalatha, N.G. Sastry and R. Saroja. 2001. "Intra-urban differences in the prevalence of the metabolic syndrome in southern India - the Chennai Urban Population study (CUPS No. 4)." Diabetic Medicine, 18(4): 280-287.

Mohan, V., C. S. Shanthirani, Deepa Mohan, Deepa Raj, R.I. Unnikrishnan and M. Datta. 2006. "Mortality Rates Due to Diabetes in a Selected Urban South Indian Population - The Chennai Urban Population Study [CUPS -16]." Journal of Association of Physicians in India, 54: 113-117.

Misra, A. R.M. Pandey, J.R. Devi, R. Sharma, N.K.Vikram, N. Khanna. 2001. "High prevalence of diabetes, obesity and dyslipidaemia in urban slum population in northern India." Lnt. J. Obes. Relat. Metab. Disord., 25: 1722-1729.

Nadkarni, M. 1954. Indian Materia Medica. Mumbai: Popular Book Depot.

Official home page of The Hitavada. 2006. Hyderabad emerging as diabetes capital of India. Retrieved April 23, 2006 from http://news.hitavadaonline.com/ news/index.php? mode $=$ single $\&$ page $=11 \& n=6546$.

Official home page of ChennaiOnline, Health. 2006.Diabetes Risk Score developed Retrieved May 12, 2006 from http://www.chennaionline.com/ health/News/2005/09diabetes.asp.

Official home page of Tribes. 2006. Retrieved July 12 from http://tribal.nic.in/tribes.html.

Official home page of Tribes. 2006. Retrieved July 12 from http://tribal.nic.in/theconstitutionbystate.html 
Official site of WEBINDIA123.com, News. 2006 Hyderabad has emerged as diabetes capital of India: Expert Hyderabad Jan 26, 2006. Retrieved April 19, 2006 from http://news.webindia123.com/news/ showdetails.asp?id=231251\&cat=Health .

Official home page of The Hitavada. 2006. Hyderabad emerging as diabetes capital of India dated Feb 17 2006. Retrieved April 19, 2006 from http:// news.hitavadaonline.com/news/index.php? mode $=$ single \&page $=11 \& \mathrm{n}=6546$

Official home page of wiseGeek. 2006. What is a banyan tree. Retrieved July 8, 2006 from http:// www.wisegeek.com/what-is-a-banyan-tree.htm.

Official home page of wiseGeek. 2006. What is a banyan tree. Retrieved July 8, 2006 from http:// www.herbalgram.org/herbclip/review.asp?i=43536.

Official home page of Plant Cultures, exploring plants and people. Banyan - traditional medicine. Retrieved July 8, 2006 from http://www.plantcultures.org.uk/ plants/banyan_traditional_medicine.html.

Official home page of hashmi.com, Rebuibing herbal: herbs and spices. Banyan. Retrieved July 8, 2006 from http://www.hashmi.com/banyan.html.

Official home page of NRDC (1953-2003) National Research Development Corporation. Bioactive compounds from natural plant products such as fenugreek seed(methi), banyan bark and garlic clove for control of diabetes \& heart diseases. Retrieved July 8, 2006 from http://www.nrdcindia.com/pages/ bioactivecompounds.htm.

Official home page of Health and Yoga, The Way Of Life The Complete Care. Anti Diabetic Powder. Retrieved July 15, 2006 from http://www.healthand yoga.com/html/product/diabetic.html.

Official site of WEBINDIA123.com, Diabetes, Care and diet. Retrieved March 24, 2006 from http:// www.webindia123.com/health/disease/diab/care.htm.

Official home page of Plant Cultures, exploring plants and people. Curry leaf - western medicine. Diabetes. Retrieved July 8, 2006 from http://www.plant cultures.org.uk/plants/curry_leaf_western

Ornish, D. 1996. Program for Reversing Heart Disease. New York: Ivy Books..

Raheja, B.S., N. G. Talwalkar and S. K. Suttarwalla. February, 1970. "Ischaemic heart disease in diabetes." J. Assoc. Physicians India, 18(2): 261-7.

Rahman, A.U. and K. Zaman. 1989. "Medicinal Plants with Hypoglycemic Activity." J. Ethnopharmacol., 26: $1-55$.

Ramachandran, A., C. Snehalatha, A. Kapur, V. Vijay, V. Mohan, A.K. Das, P.V. Rao, C.S. Yajnik, K.M Prasanna Kumar, and Jyotsna D. Nair. 1990. "High prevalence of diabetes and impaired glucose tolerance in India: National Urban Diabetes Survey." Diabetes Metabolism Review, 6: 125-146.

Ramachandran, A., C. Snehalatha, A. Kapur, V. Vijay, V. Mohan and A.K. Das. 2001. "For Diabetes Epidemiology Study Group in India (DESI). High prevalence of diabetes and impaired glucose tolerance in India: National Urban Diabetes Survey." Diabetologia, 44: 1094-101.
Ramachandran Ambady, Chamukuttan Snehalatha, and Viswanathan, Vijay. 2003. "Explosion of type 2 diabetes in the Indian subcontinent." International Diabetes Monitor, 15(5): 1-6.

Ramaiya, K.L., V.R. Kodali, and K.G. Alberti. 1990. "Epidemiology of diabetes in Asians of the Indian subcontinent." Diabetes Metab. Rev., 6: 125-46.

Rao, V.G., Rajeev Yadav, C.K. Dolla, Surendra Kumar, M. K. Bhondeley and Mahendra Ukey. 2005. "Undernutrition \& childhood morbidities among tribal preschool children." Indian Journal of Medical Research, 43-47.

Robin, D. Tribhuwan and Karen Sherry. 2004. Health, Medicine and Nutrition of the Tribals. New Delhi: Discovery Publishing House.

Robin, D. Tribhuwan. 2004. Health of Primitive Tribes. New Delhi: Discovery Publishing House.

Sanders, T.A.B., F.R. Oakley, G.J. Miller and K. A. Mitropoulous. 1985. Influence of $n-6$ versus n-3 polyunsaturated fatty acids in diet low in saturated fatty acid decreases during long term compliance with a lipid lowering diet. J. Internal Medicine, 59: 249-258.

Santana, R.M. 1996. "Some notes on urban traditional medicines." Ancient Sc. of Life, 16(1): 34-40.

Saraswati, Baidyanath. 2004. Cultures and Cosmos: The Cosmic Anthropological Principle. New Delhi: Aryan Books International.

Sarkar, Amitabha and Samira Dasgupta. 2000. EthnoEcology of Indian Tribes: Diversity in Cultural Adaptation. Delhi: Rawat.

Satyavati, G.V., Niraj Tandon, Madhu Sharma. 1989. "Indigenous plant drugs for diabetes mellitus." Diabetes Bulleta, 181 Q: 1-32.

Seshadri, C.V. 1993. "Indigenous sciences and technologies - the PPST endeavor." Paper presented in Congress on Traditional Sc and Technologies of India in IIT, Mumbai, November $28^{\text {th }}$ to December $3^{\text {rd }}, 1993$.

Shrotri, D. S. and R. Aiman. 1960. "The relationship of the post absorptive state to the hypoglycemic action. Studies on ficus bengalensis and ficus glomerata." Ind. J. Med. Res., 48: 162.

Singh, A. K. 1993. Tribes and Tribal Life, Volume 3: Approaches to the Development in Tribal Context. New Delhi: Sarup \& Sons.

Singh, N., S. D. Tyagi, and S. C. Agarwal. 1992. "Study of antidiabetic effects of alcoholic extract of ficus bengalensis (Linn) on diabetic albino rats." J. Res. Ayurv. Sidha., 13(1-2): 56-61.

Vohra, S.B. and G. C. Parasar. 1969."Phytochemical and pharmacological studies on ficus bengalensis Linn." Ind. J. Physiol. and Pharmacol., 13(3): 143.

Vohra, S.B. and G. C. Parasar. 1970. "Antidiabetic studies on ficus bengalensis linn." Ind. J. Pharmacy, 32(3): 68.

Wahrenberg Hans, Katarina Hertel, Britt-Marie Leijonhufvud, Lars-Göran Persson, Eva Toft, Peter Arner. 2005. "Use of waist circumference to predict insulin resistance: retrospective study." $B M J, 330$ : $1363-1364$ 